\title{
LINEÁRIS PROGRAMOK A MAXIMÁLIS ÉLSÚLYÚ KLIKK PROBLÉMÁRA
}

\author{
SZABÓ SÁNDOR, SZTOJKOVICS DÓRA
}

\begin{abstract}
Egy adott gráfban a maximális élsúlyú klikk megtalálása egy ismert és fontos probléma, sok alkalmazással. A probléma megoldására léteznek a lineáris programozás eszközeit, valamint lineáris programozással nem kapcsolatos kombinatorikus alapú, keresési fát használó algoritmusok is. Egy olyan tanulmányhoz [6] füzünk megjegyzéseket, amelyben a szerzők egy kombinatorikus alapú algoritmust hasonlítottak össze kettő lineáris programozás, és egy kvadratikus programozás alapú algoritmussal. Az [1] és [6] cikkben szereplő egyik programot módosítjuk. A módosításokhoz a gráf csúcsainak és éleinek színezésével jutunk. Az új programokat numerikus kísérletekben teszteltük.
\end{abstract}

\section{Bevezetés}

Legyen $G=(V, E), V=\left\{v_{1}, v_{2}, \ldots, v_{n}\right\}$, egy véges, egyszerü, irányítatlan gráf. Tekintsük $V$-nek egy $C \subseteq V$ részhalmazát. $C$ klikk $G$-ben, ha bármely két csúcsa között fut él, azaz minden $v_{i}, v_{j} \in C(1 \leq i, j \leq n, i \neq j)$ esetén $\left\{v_{i}, v_{j}\right\} \in E$. Ha $|C|=k$, akkor azt mondjuk, hogy $C$ egy $k$-klikk. $C$ maximum klikk $G$-ben, ha minden $K \subseteq V$ klikk esetén $|K| \leq|C|$. Ekkor a klikk méretét (csúcsainak számát) az $\omega(G)$ szimbólummal jelöljük és a $G$ klikkszámának nevezzük. Ha $\omega(G)=k$, akkor a klikk éleinek száma $\left(\begin{array}{l}k \\ 2\end{array}\right)=\frac{k(k-1)}{2}$. $C$ maximális klikk $G$-ben, ha tovább nem bővíthető, azaz bármely $v_{i} \in V, v_{i} \notin C$ csúcsot hozzávéve $C$-hez a kapott $C \cup\left\{v_{i}\right\}$ halmaz már nem alkot klikket. A definícióból következik, hogy minden maximum klikk maximális, de nem minden maximális klikk maximum klikk.

$G$ gráf minden $\{u, v\} \in E$ éléhez rendeljünk hozzá egy $w_{e}(u, v)$ nemnegatív értéket, így egy élsúlyozott gráfot kapunk. Keressünk $G$-ben egy olyan klikket, amelyben az élek súlyának összege maximális. Ez egy sokat vizsgált NP-nehéz probléma fontos alkalmazásokkal ([4], [5], [7], [8]), amit maximális élsúlyú klikk problémának nevezünk. A [6] cikkben a szerzők mutatnak egy olyan kombinatorikus alapú algoritmust, amely gyorsabban számolt az általuk tesztelt gráfokon, mint más, lineáris programozás alapú algoritmusok. Célunk a cikkben mutatott vegyes-egészértékű program módosítása volt, amihez lokális csúcsszínezést és élszínezést, valamint globális élszínezést használtunk. 


\subsection{Csúcsszínezés}

Színezzük ki $G$ gráf csúcsait úgy, hogy a következő feltételek teljesüljenek:

1. Minden csúcsnak pontosan egy színe van.

2. Éllel összekötött csúcsok különböző színűek.

Ha a fenti feltételek teljesülnek, akkor a csúcsok jó színezéséről beszélünk. Tegyük fel, hogy $G$ csúcsai $k$ színnel jól színezhetők, de $k-1$ színnel már nem. Ekkor a $k$ számot $G$ kromatikus számának nevezzük, és $\chi(G)$ szimbólummal jelöljük. $\chi(G)$ meghatározása egy NP-nehéz optimalizálási probléma.

\section{2. Élszínezés}

Színezzük ki $G$ gráf éleit úgy, hogy teljesüljenek az alábbi feltételek:

1. Minden élnek pontosan egy színe van.

2. G-ben bármely háromszög (3-klikk) mindhárom éle különböző színű.

3. G-ben bármely teljes négyszög (4-klikk) mind a hat éle különböző színű.

Ha ezek a kritériumok teljesülnek, akkor az élek élesített ${ }^{1}$ jó színezéséről beszélünk. Az élek jó színezése egy ismert fogalom, amit akkor használunk, ha az egy közös csúcsra illeszkedő élek különböző színüek. A mi esetünkben egy csúcsra illeszkedhetnek azonos színü élek is.

A [6] cikk szerzői olyan vegyes-egészértékü programot használtak az összehasonlításban, melyben a változók egy része bináris volt. Mi olyan szempontból vizsgáltuk a programot, hogy a lineáris relaxációja, amelyben a bináris változóknak megengedjük, hogy tetszőleges 0 és 1 közötti valós értéket vegyenek fel, mennyire közelíti jól az optimumot. Az így kapott lineáris programot a vegyes-egészértékü program lineáris relaxációjának nevezzük. Egy egészértékű vagy vegyes-egészértékü program összes megengedett megoldása a lineáris relaxációjának is megengedett megoldása lesz. Egy maximum probléma esetén az egészértékü vagy vegyesegészértékü program lineáris relaxációjának optimum értéke mindig felső becslést ad az eredeti program optimum értékére.

Az [1] és [6] cikkekben használt egészértékü és vegyes-egészértékü programok lineáris relaxációinál szeretnénk erősebb lineáris relaxációkat kapni. A lineáris relaxációk összehasonlításának két módszerét használjuk, egy elméleti jellegüt és egy numerikus számolásokon alapuló módszert:

\footnotetext{
${ }^{1} \mathrm{Az}$ élesített itt nem azt jelenti, hogy javított, vagy erős, hanem azt, hogy az élszínek különbözőségét a 3- és 4-klikkek élei alapján követeljük meg.
} 
1. Ellenőrizzük (ahol ez lehetséges), hogy az egyik lineáris program megengedett megoldásainak halmaza tartalmazza-e a másik lineáris program megengedett megoldásainak halmazát.

2. Gondosan választott tesztfeladatok esetén azt tapasztaljuk, hogy az új megfogalmazás tipikusan jobb felső becsléseket ad, mint a régi.

\section{Egészértékü programok a maximum klikk problémára a szakirodalomból}

A maximális élsúlyú klikk probléma megoldása előtt tekintsünk olyan egészértékü programokat, amelyek megoldják a maximum klikk problémát.

Legyen $G=(V, E), V=\left\{v_{1}, v_{2}, \ldots, v_{n}\right\}$ továbbra is egy véges, egyszerü, irányítatlan gráf. Mutatunk három lineáris programozás alapú algoritmust, amelyek megadják $G$-ben a maximum klikket. Ezekben az egészértékü programokban nem vesszük figyelembe az élsúlyokat.

\section{1. Él átfogalmazás}

Legyen $C$ egy klikk $G$-ben, és vezessük be az $x_{1}, x_{2}, \ldots, x_{n}$ döntési változókat. A változók száma megegyezik $G$ csúcsainak számával. Az $x_{i}$ változó értéke 1 , ha $v_{i}$ szerepel a klikkben $(1 \leq i \leq n)$, 0 különben:

$$
x_{i}= \begin{cases}1, & \text { ha } v_{i} \in C, \\ 0, & \text { ha } v_{i} \notin C .\end{cases}
$$

Ekkor a célfüggvény a következő alakban írható:

$$
\sum_{i=1}^{n} x_{i} \rightarrow \max
$$

Ez maximalizálni fogja a csúcsok számát. Két változó összege akkor és csak akkor lehet 2-vel egyenlő, ha a megfelelő csúcsok elemei $C$-nek, ekkor össze vannak kötve éllel. Így, ha két csúcs között nem fut él, akkor mindkettő nem szerepelhet egy klikkben, és a megfelelő változók összege legfeljebb 1 lehet. A feltételek a következők:

$$
x_{i}+x_{j} \leq 1, \quad \text { ha }\left\{v_{i}, v_{j}\right\} \notin E .
$$

Az él átfogalmazással kapott egészértékü program:

$$
\begin{array}{cl}
\text { maximum: } & \sum_{i=1}^{n} x_{i} \\
\text { feltételek: } & x_{i}+x_{j} \leq 1, \quad\left(v_{i}, v_{j}\right) \notin E \\
& x_{i} \in\{0,1\}, \quad v_{i} \in V .
\end{array}
$$


A következő két formálisabb állítás bizonyítása kiolvasható a fenti megfontolásokból.

Legyen $U \subseteq V$. Definiáljuk az $\underline{\alpha}^{T}=\left(\alpha_{1}, \alpha_{2}, \ldots, \alpha_{n}\right)$ vektort úgy, hogy

$$
\alpha_{i}= \begin{cases}1, & \text { ha } v_{i} \in U, \\ 0, & \text { ha } v_{i} \notin U .\end{cases}
$$

Az $\underline{\alpha}^{T}$ vektort az $U$ karakterisztikus vektorának nevezzük.

2.1. Állítás. Ha $C \subseteq V$ klikk $G$-ben, akkor $C$ karakterisztikus vektora, $\underline{\alpha}^{T}$, megengedett megoldása (1)-nek.

2.2. Állítás. Ha $\underline{\alpha}^{T}$ megengedett megoldása (1)-nek, és $\underline{\alpha}^{T}$ a $C \subseteq V$ karakterisztikus vektora, akkor $C$ klikk $G$-ben.

\subsection{Független halmaz átfogalmazás}

A független halmaz átfogalmazás célfüggvénye és a változói ugyanazok, mint az él átfogalmazás esetén. Legyen $I \subseteq V$ olyan halmaz, amelyben semelyik két csúcs között nem fut él, azaz minden $v_{i}, v_{j} \in I(1 \leq i, j \leq n)$ esetén $\left(v_{i}, v_{j}\right) \notin E$. Ekkor azt mondjuk, hogy $I$ független halmaz. Ha minden $J \subseteq V$ független halmazra $|J| \leq|I|$, akkor $I$ maximum független halmaz. $I$ maximális független halmaz, ha tovább nem bővíthetö, azaz, ha bármely $v_{i} \in V, v_{i} \notin I$ csúcsot hozzávéve $I$-hez a kapott $I \cup\left\{v_{i}\right\}$ halmaz már nem független. Minden maximum független halmaz maximális, de egy maximális független halmaz nem feltétlenül maximum független halmaz.

Egy független halmazban semelyik két csúcs között sem fut él, ezért a halmaz elemei közül legfeljebb egy csúcs szerepelhet egy klikkben:

$$
\sum_{v_{i} \in I} x_{i} \leq 1, \quad \text { ahol } I \text { maximális független halmaz. }
$$

A független halmaz átfogalmazással kapott egészértékű program:

$$
\begin{array}{ll}
\text { maximum: } & \sum_{i=1}^{n} x_{i} \\
\text { feltételek: } & \sum_{v_{i} \in I} x_{i} \leq 1, \quad I \text { maximális független halmaz } \\
& x_{i} \in\{0,1\}, \quad v_{i} \in V .
\end{array}
$$

A következő két állítás indoklása hasonlít a 2.1. és 2.2. Állítások igazolásához.

2.3. Állítás. Ha $C \subseteq V$ klikk $G$-ben, akkor $C$ karakterisztikus vektora, $\underline{\alpha}^{T}$, megengedett megoldása (2)-nek. 
2.4. Állítás. Ha $\underline{\alpha}^{T}$ megengedett megoldása (2)-nek, és $\underline{\alpha}^{T}$ a $C \subseteq V$ karakterisztikus vektora, akkor $C$ klikk $G$-ben.

A maximális független halmazok előállításához egy NP-nehéz feladatot kell megoldani, és így a független halmaz átfogalmazás nem tűnik gyakorlatilag kivitelezhetőnek. A helyzet ennél árnyaltabb. Amikor a $G$ gráfnak sok éle van, akkor a független halmazok felsorolása megoldható a Bronn-Kerbosch algoritmussal. Amikor $G$-nek kevés éle van, akkor a maximum klikk probléma oldható meg elfogadható ráfordítással.

\subsection{A Croce-Tadei átfogalmazás}

Az átfogalmazás megtalálható az [1] cikkben. A célfüggvényt és változókat az előző esetekhez hasonlóan kapjuk.

Legyen $\bar{N}\left(v_{i}\right)$ azon csúcsok halmaza, amelyek nem szomszédai $v_{i}$-nek $G$-ben, azaz $\bar{N}\left(v_{i}\right)=\left\{u:\left\{v_{i}, u\right\} \notin E, u \in V\right\}$. Jelölje $\bar{N}_{i}$ a $v_{i}$ csúcs nemszomszédainak számát, $\bar{N}_{i}=\left|\bar{N}\left(v_{i}\right)\right|$. Ha $v_{i}$ eleme a $C$ klikknek, akkor $\bar{N}\left(v_{i}\right)$ halmaz semelyik eleme nem szerepelhet a klikkben, amit a következő feltételekkel írhatunk le:

$$
\bar{N}_{i} x_{i}+\sum_{v_{j} \in \bar{N}\left(v_{i}\right)} x_{j} \leq \bar{N}_{i} .
$$

Ez az egyenlőtlenség a 2.1. alfejezetbeli (1) egészértékű program egyenlőtlenségei közül a $v_{i}$-re illeszkedő nem-élekhez tartozóknak az összege. A Croce-Tadei átfogalmazással kapott egészértékü program:

$$
\begin{array}{cl}
\text { maximum : } & \sum_{i=1}^{n} x_{i} \\
\text { feltételek: } & \bar{N}_{i} x_{i}+\sum_{v_{j} \in \bar{N}\left(v_{i}\right)} x_{j} \leq \bar{N}_{i}, \quad v_{i} \in V \\
& x_{i} \in\{0,1\}, \quad v_{i} \in V .
\end{array}
$$

2.5. Állítás. Ha $C \subseteq V$ klikk $G$-ben, akkor $C$ karakterisztikus vektora, $\underline{\alpha}^{T}$, megengedett megoldása (3)-nak.

Bizonyítás. Legyen $C$ klikk $G$-ben, és tegyük fel indirekt módon, hogy $\underline{\alpha}^{T}$ nem megengedett megoldás, azaz létezik olyan $1 \leq i \leq n$, amire

$$
\bar{N}_{i} \alpha_{i}+\sum_{v_{j} \in \bar{N}\left(v_{i}\right)} \alpha_{j} \geq \bar{N}_{i}+1
$$

Két esetet különböztetünk meg aszerint, hogy $\alpha_{i}=0$ vagy $\alpha_{i}=1$. 
1. eset: Ha $\alpha_{i}=0$, akkor azt az egyenlőtlenséget kapjuk, hogy

$$
\sum_{v_{j} \in \bar{N}\left(v_{i}\right)} \alpha_{j} \geq \bar{N}_{i}+1
$$

$\alpha_{j}$ értéke legfeljebb 1 lehet, és $\left|\bar{N}\left(v_{i}\right)\right|=\bar{N}_{i}$, innen következik, hogy

$$
\sum_{v_{j} \in \bar{N}\left(v_{i}\right)} \alpha_{j} \leq \bar{N}_{i}
$$

Ellentmondásra jutottunk.

2. eset: Ha $\alpha_{i}=1$, akkor azt kapjuk, hogy

$$
\bar{N}_{i}+\sum_{v_{j} \in \bar{N}\left(v_{i}\right)} \alpha_{j} \geq \bar{N}_{i}+1 .
$$

Mindkét oldalból kivonva $\bar{N}_{i}$-t a

$$
\sum_{v_{j} \in \bar{N}\left(v_{i}\right)} \alpha_{j} \geq 1
$$

egyenlőtlenség adódik. Ekkor létezik $1 \leq k \leq n$, amelyre $v_{k} \in \bar{N}\left(v_{i}\right)$, azaz $\left\{v_{i}, v_{k}\right\} \notin E$ és $\alpha_{k}=1$. Mivel $\alpha_{i}=1$ és $\alpha_{k}=1$, ezért $v_{k} \in C$ és $v_{i} \in C$. $C$ klikk, ezért $\left\{v_{i}, v_{k}\right\} \in E$. Ellentmondásra jutottunk.

Mindkét esetben ellentmondásra jutottunk, ezzel az állítást beláttuk.

2.6. ÁlLíTÁs. Ha $\underline{\alpha}^{T}$ megengedett megoldása (3)-nak, és $\underline{\alpha}^{T}$ a $C \subseteq V$ karakterisztikus vektora, akkor $C$ klikk $G$-ben.

Bizonyítás. Legyen $\underline{\alpha}^{T}$ megengedett megoldása (3)-nak, és tegyük fel indirekt módon, hogy $C$ nem klikk $G$-ben. Ekkor létezik $1 \leq i, k \leq n, i \neq k$, amire $v_{i}, v_{k} \in C$, de $\left\{v_{i}, v_{k}\right\} \notin E$. Következik, hogy $\alpha_{i}=1, \alpha_{k}=1$ és $v_{k} \in \bar{N}\left(v_{i}\right)$. $\underline{\alpha}^{T}$ megengedett megoldás, ezért az

$$
\bar{N}_{i} \alpha_{i}+\sum_{v_{j} \in \bar{N}\left(v_{i}\right)} \alpha_{j} \leq \bar{N}_{i}
$$

feltétel teljesül. Behelyettesítve $\alpha_{i}$ és $\alpha_{k}$ értékeit azt kapjuk, hogy

$$
\bar{N}_{i}+1+\sum_{v_{j} \in \bar{N}\left(v_{i}\right), j \neq k} \alpha_{j} \leq \bar{N}_{i} .
$$


Átrendezve az egyenlőtlenséget

$$
\sum_{v_{j} \in \bar{N}\left(v_{i}\right), j \neq k} \alpha_{j} \leq-1
$$

adódik. Ellentmondásra jutottunk, mivel az összeg minden tagja nemnegatív. Ezzel az állítást beláttuk.

A három egészértékü program ekvivalens egymással abban az értelemben, hogy ugyanazok a megengedett megoldásaik és az optimum értékeik.

Az él átfogalmazásban $\mathcal{O}\left(\left(\begin{array}{l}n \\ 2\end{array}\right)-|E|\right)=\mathcal{O}\left(n^{2}\right)$ feltétel jelenik meg. Vannak olyan $n$ csúcsú gráfok, amelyek $\mathcal{O}\left(2^{n}\right)$ maximális klikket tartalmaznak, és olyanok, melyekben $\mathcal{O}\left(2^{n}\right)$ független halmaz található [3]. Ezeknél a gráfoknál, ha a független halmaz átfogalmazással szeretnénk megtalálni a maximum klikket, akkor nagyon sok feltételt kapunk az egészértékü programban. Ezekkel szemben a Croce-Tadei átfogalmazás csak $n$ feltételt tartalmaz, melyeket könnyen meghatározhatunk a szomszédsági mátrixból.

A maximális élsúlyú klikk probléma megoldására egy lehetőség, hogy a fenti programokat további feltételekkel egészítjük ki. A [6] cikkben a szerzők az él átfogalmazást bővítették újabb egyenlőtlenségekkel. A Croce-Tadei átfogalmazásban általában kevesebb feltétel szerepel, ezért ezt fogjuk használni az él átfogalmazás helyett.

\section{A maximális élsúlyú klikk probléma}

A maximális élsúlyú klikk probléma megoldására a [6] cikkben kettő lineáris programozás alapú, egy kvadratikus programozás alapú és egy kombinatorikus alapú algoritmust mutatnak a szerzők. A tesztelt gráfok esetén a leggyorsabb algoritmus a kombinatorikus alapú volt, amit a vegyes-egészértékű program követett. Ennek a módosításával foglalkoztunk.

Legyen $G=(V, E), V=\left\{v_{1}, v_{2}, \ldots, v_{n}\right\}$, egy véges, egyszerü, irányítatlan gráf, ahogy eddig is. Jelölje $N\left(v_{i}\right)$ azon csúcsok halmazát, amelyek szomszédai $v_{i} \in V$ nek. Legyen $N^{+}\left(v_{i}\right)=N\left(v_{i}\right) \cap\left\{v_{j}: j>i\right\}$, és legyen $U_{i}=\sum_{v_{j} \in N^{+}\left(v_{i}\right)} w_{e}\left(v_{i}, v_{j}\right)$.

\subsection{Vegyes-egészértékü program [6]}

A következő vegyes-egészértékü program optimális megoldása megadja a maximális élsúlyú klikket $G$-ben: 


$$
\begin{array}{ll}
\text { maximum: } & \sum_{i=1}^{n-1} z_{i} \\
\text { feltételek: } & x_{i}+x_{j} \leq 1, \quad\left\{v_{i}, v_{j}\right\} \notin E \\
& z_{i} \leq U_{i} x_{i}, \quad v_{i} \in V \backslash\left\{v_{n}\right\} \\
& z_{i} \leq \sum_{v_{j} \in N^{+}\left(v_{i}\right)} w_{e}\left(v_{i}, v_{j}\right) x_{j}, \quad v_{i} \in V \backslash\left\{v_{n}\right\} \\
& x_{i} \in\{0,1\}, \quad v_{i} \in V .
\end{array}
$$

A (4) vegyes-egészértékü program az él átfogalmazás kiegészítése a (4.2), (4.3) feltételekkel, új célfüggvénnyel és a $z_{1}, z_{2}, \ldots, z_{n-1}$ változókkal. A célfüggvény az $n-1$ darab új változó összegének a maximuma:

$$
\sum_{i=1}^{n-1} z_{i} \rightarrow \max
$$

Legyen $C \subseteq V$ klikk $G$-ben és $\underline{\alpha}^{T}$ a $C$ karakterisztikus vektora. Legyen $\beta^{T}=$ $\left(\beta_{1}, \beta_{2}, \ldots, \beta_{n-1}\right)$, ahol $\beta_{i}(1 \leq i \leq n-1)$ értéke nem nagyobb, mint a $v_{i}$ csúcsból az $i$-nél nagyobb indexü $C$-beli csúcsokba futó élek súlyának összege, ha $v_{i} \in C$, ellenkező esetben pedig legfeljebb 0:

$$
\beta_{i} \leq\left\{\begin{array}{cl}
\sum_{v_{j} \in N^{+}\left(v_{i}\right) \cap C} w_{e}\left(v_{i}, v_{j}\right), & \text { ha } v_{i} \in C, \\
0, & \text { ha } v_{i} \notin C .
\end{array}\right.
$$

Ekkor a $\sum_{i=1}^{n-1} \beta_{i}$ összeg maximuma a $C$ klikk élsúlyainak összegével egyezik meg.

3.1. Állítás. $A z\left(\underline{\alpha}^{T}, \underline{\beta}^{T}\right)^{T}$ vektor megengedett megoldása (4)-nek.

Bizonyítás. A 2.1. Állítás kimondja, hogy ha $C$ klikk $G$-ben akkor, a (4.2) feltételek teljesülnek.

Tekintsük a (4.3) feltételeket. Ha $v_{i} \in C$, akkor

$$
\beta_{i} \leq \sum_{v_{j} \in N^{+}\left(v_{i}\right) \cap C} w_{e}\left(v_{i}, v_{j}\right) \quad \text { és } \quad U_{i} \alpha_{i}=\sum_{v_{j} \in N^{+}\left(v_{i}\right)} w_{e}\left(v_{i}, v_{j}\right) .
$$

$\left(N^{+}\left(v_{i}\right) \cap C\right) \subseteq N^{+}\left(v_{i}\right)$ és a súlyok nemnegatívak, ezért $\beta_{i} \leq U_{i} \alpha_{i}$. Ha $v_{i} \notin C$, akkor $\beta_{i} \leq 0$ és $U_{i} \alpha_{i}=0$, tehát az egyenlőtlenség ebben az esetben is teljesül.

Tekintsük a (4.4) feltételeket. Ha $v_{i} \in C$, akkor

$$
\beta_{i} \leq \sum_{v_{j} \in N^{+}\left(v_{i}\right) \cap C} w_{e}\left(v_{i}, v_{j}\right)=\sum_{v_{j} \in N^{+}\left(v_{i}\right)} w_{e}\left(v_{i}, v_{j}\right) \alpha_{j} .
$$


Ha $v_{i} \notin C$, akkor $\beta_{i} \leq 0$, a jobb oldalon pedig egy nemnegatív érték szerepel, tehát az egyenlőtlenség mindkét esetben teljesül.

3.2. ÁllítÁs. Ha $\left(\underline{\alpha}^{T}, \underline{\beta}^{T}\right)^{T}$ megengedett megoldása (4)-nek, akkor az $\underline{\alpha}^{T}$ karakterisztikus vektorhoz tartozó $C \subseteq V$ halmaz klikk $G$-ben, valamint ha $v_{i} \in C$, akkor

$$
\beta_{i} \leq \sum_{v_{j} \in N^{+}\left(v_{i}\right) \cap C} w_{e}\left(v_{i}, v_{j}\right),
$$

és $\beta_{i} \leq 0$, ha $v_{i} \notin C$.

Bizonyítás. A 2.2. Tételből következik, hogy a (4.2) feltételek miatt $C$ klikk $G$-ben.

Ha $v_{i} \notin C$, akkor a (4.3) feltételekből adódik, hogy $\beta_{i} \leq 0$, a (4.4) egyenlőtlenségekből pedig következik, hogy

$$
\beta_{i} \leq \sum_{v_{j} \in N^{+}\left(v_{i}\right)} w_{e}\left(v_{i}, v_{j}\right) \alpha_{j}
$$

A két korlát körül az első erősebb, ezért $\beta_{i} \leq 0$ teljesül.

Ha $v_{i} \in C$, akkor a (4.3) egyenlőtlenségekből azt kapjuk, hogy $\beta_{i} \leq U_{i}$, és a (4.4) feltételekböl következik, hogy

$$
\beta_{i} \leq \sum_{v_{j} \in N^{+}\left(v_{i}\right)} w_{e}\left(v_{i}, v_{j}\right) \alpha_{j}=\sum_{v_{j} \in N^{+}\left(v_{i}\right) \cap C} w_{e}\left(v_{i}, v_{j}\right) .
$$

Mivel

$$
\sum_{v_{j} \in N^{+}\left(v_{i}\right) \cap C} w_{e}\left(v_{i}, v_{j}\right) \leq \sum_{v_{j} \in N^{+}\left(v_{i}\right)} w_{e}\left(v_{i}, v_{j}\right)=U_{i}
$$

ezért

$$
\beta_{i} \leq \sum_{v_{j} \in N^{+}\left(v_{i}\right) \cap C} w_{e}\left(v_{i}, v_{j}\right)
$$

A tételekből következik, hogy az optimális megoldás megadja a $G$-beli maximális élsúlyú klikket.

\section{4. Új matematikai programok a maximális élsúlyú klikk problémára}

Ebben a fejezetben a (4) vegyes-egészértékü program (4.2) és (4.3) feltételein módosítunk. A Croce-Tadei egyenlőtlenségek esetén, ha $x_{i}=0$, akkor az $i$-edik 
feltétel megengedi, hogy $v_{i}$ bármelyik nemszomszédját bevegyük a klikkbe. Ennek az egyenlőtlenségnek a módosítására több lehetőségünk is van.

A [6]-ban szereplő (4) program helyett az alábbi programot fogjuk használni.

$$
\begin{array}{ll}
\text { maximum: } & \sum_{i=1}^{n-1} z_{i} \\
\text { feltételek: } \quad & C_{i} x_{i}+\sum_{v_{j} \in \bar{N}\left(v_{i}\right)} x_{j} \leq C_{i}, \quad v_{i} \in V \\
& z_{i} \leq M_{i} x_{i}, \quad v_{i} \in V \backslash\left\{v_{n}\right\} \\
& z_{i} \leq \sum_{v_{j} \in N^{+}\left(v_{i}\right)} w_{e}\left(v_{i}, v_{j}\right) x_{j}, \quad v_{i} \in V \backslash\left\{v_{n}\right\} \\
& \sum_{i=1}^{n} x_{i} \leq S \\
& x_{i} \in\{0,1\}, \quad v_{i} \in V .
\end{array}
$$

$C_{i}$ megválasztását a 4.1. és a 4.2. alfejezetekben, $M_{i}$ választását a 4.3 . alfejezetben, $S$ választását pedig a 4.4. alfejezetben fogjuk részletezni.

\subsection{Az (5.2) korlátban a $C_{i}$ megválasztása lokális csúcsszínezéssel}

Tekintsük a Croce-Tadei egyenlőtlenségek $i$-edik csúcsra vonatkozó (3.2) feltételét, és színezzük ki $v_{i}$ nemszomszédait jól. Alkalmazzuk a mohó színezőt: az első csúcs színe legyen 1. A második csúcs színe is legyen 1, ha nem szomszédja az elsőnek és 2, ha szomszédja. Tegyük fel, hogy kiszíneztünk $k$ csúcsot $s$ színnel jól. Tekintsük azt a legkisebb színszámú színosztályt, amelyben egyik csúcs sem szomszédja $v_{k+1}$-nek. Ha van ilyen, akkor $v_{k+1}$ is bekerül ebbe a színosztályba, ha nincs, akkor $v_{k+1}$ színe legyen $s+1$. Mivel egy klikkben bármely két csúcs között fut él, ezért minden csúcs különböző színű lesz. Így a színosztályok száma felső becslést ad a maximum klikk méretére.

A következő állításokban azt fogjuk megmutatni, hogy az eredeti (4) vegyesegészértékü program

- (4.2) feltételét lecserélhetjük az (5.2) feltételre. Az így kapott programot jelöljük (6)-tal.

- (4.3) feltételét lecserélhetjük az (5.3) feltételre. Az így kapott programot jelöljük (7)-tel.

Legyen $G=(V, E), V=\left\{v_{1}, v_{2}, \ldots, v_{n}\right\}$, egy véges, egyszerü, irányítatlan gráf. Színezzük ki minden csúcs esetén a csúcs nemszomszédaiból álló részgráfot a fenti színezéssel. Jelölje $C_{i}$ a $v_{i}$ nemszomszédai által kifeszített részgráf esetén kapott felső becslést a részgráfban található maximum klikk méretére. A Croce-Tadei egyenlőtlenségek $i$-edik feltételét úgy élesíthetjük, ha $\bar{N}_{i}$ helyére $C_{i}$-t írunk. 
Jelölje $\bar{\omega}_{i}$ az $i$-edik csúcs nemszomszédai által kifeszített $G$-beli részgráfban található maximum klikk méretét. $C_{i}$ felső becslés a klikkméretre, ezért $\bar{\omega}_{i} \leq C_{i}$.

4.1. Állítás. Legyen $C \subseteq V$ karakterisztikus vektora $\underline{\alpha}^{T}$, és legyen $\underline{\beta}^{T}=$ $\left(\beta_{1}, \beta_{2}, \ldots, \beta_{n-1}\right)$, ahol minden $1 \leq i \leq n-1$ esetén

$$
\beta_{i} \leq \sum_{v_{j} \in N^{+}\left(v_{i}\right) \cap C} w_{e}\left(v_{i}, v_{j}\right),
$$

ha $v_{i} \in C$, valamint $\beta_{i} \leq 0$, ha $v_{i} \notin C$. Ha $C$ klikk G-ben, akkor $\left(\underline{\alpha}^{T}, \underline{\beta}^{T}\right)^{T}$ megengedett megoldása (6)-nak.

Bizonyítás. Legyen $C$ klikk $G$-ben, és tegyük fel indirekt módon, hogy $\left(\underline{\alpha}^{T}, \underline{\beta}^{T}\right)^{T}$ nem megengedett megoldás. A 3.1. Állításból következik, hogy a (4.3) és $(4 . \overline{4})$ egyenlőtlenségek teljesülnek, tehát az (5.2) feltételek között létezik olyan $1 \leq i \leq n$, amire

$$
C_{i} \alpha_{i}+\sum_{v_{j} \in \bar{N}\left(v_{i}\right)} \alpha_{j} \geq C_{i}+1
$$

Két esetet különböztetünk meg aszerint, hogy $\alpha_{i}=0$ vagy $\alpha_{i}=1$.

1. eset: Ha $\alpha_{i}=0$, akkor a következő egyenlőtlenséget kapjuk:

$$
\sum_{v_{j} \in \bar{N}\left(v_{i}\right)} \alpha_{j} \geq C_{i}+1
$$

$\bar{\omega}_{i} \leq C_{i}$ miatt

$$
\sum_{v_{j} \in \bar{N}\left(v_{i}\right)} \alpha_{j} \geq \bar{\omega}_{i}+1
$$

Tekintsük a $C \cap \bar{N}\left(v_{i}\right)$ halmazt. Mivel $C$ klikk, a halmaz részhalmazai is klikket alkotnak, és az elemek száma nem nagyobb, mint az $\bar{N}\left(v_{i}\right)$ által kifeszített $G$-beli részgráfban található maximum klikk mérete: $\left|C \cap \bar{N}\left(v_{i}\right)\right| \leq \bar{\omega}_{i} \cdot\left|C \cap \bar{N}\left(v_{i}\right)\right|=$ $\sum_{v_{j} \in \bar{N}\left(v_{i}\right)} \alpha_{j}$, ezért azt kapjuk, hogy

$$
\sum_{v_{j} \in \bar{N}\left(v_{i}\right)} \alpha_{j} \leq \bar{\omega}_{i}
$$

Ellentmondásra jutottunk.

2. eset: Ha $\alpha_{i}=1$, akkor a következő egyenlőtlenség adódik:

$$
C_{i}+\sum_{v_{j} \in \bar{N}\left(v_{i}\right)} \alpha_{j} \geq C_{i}+1
$$


Mindkét oldalból kivonva $C_{i^{\text {-t }}}$

$$
\sum_{v_{j} \in \bar{N}\left(v_{i}\right)} \alpha_{j} \geq 1
$$

egyenlőtlenséget kapjuk. Ekkor létezik $1 \leq k \leq n$, amire $\alpha_{k}=1$ és $v_{k} \in \bar{N}\left(v_{i}\right)$, azaz $\left\{v_{i}, v_{k}\right\} \notin E$. Mivel $\alpha_{i}=1$ és $\alpha_{k}=1$, ezért $v_{i} \in C$ és $v_{k} \in C$. Mindkét csúcs eleme $C$-nek, ezért $\left\{v_{i}, v_{k}\right\} \in E$. Ellentmondásra jutottunk.

Mindkét esetben ellentmondásra jutottunk, ezzel az állítást beláttuk.

4.2. ÁllíTÁs. Ha $\left(\underline{\alpha}^{T}, \underline{\beta}^{T}\right)^{T}$ megengedett megoldása (6)-nak, és $\underline{\alpha}^{T}$ a $C \subseteq V$ karakterisztikus vektora, akkor $C$ klikk $G$-ben.

Bizonyítás. Legyen $\left(\underline{\alpha}^{T}, \beta^{T}\right)^{T}$ megengedett megoldása (6)-nak, és tegyük fel indirekt módon, hogy $C$ nem klikk $G$-ben. Ekkor létezik $1 \leq i, k \leq n, i \neq k$, amire $v_{i}, v_{k} \in C$, de $\left\{v_{i}, v_{k}\right\} \notin E$. Következik, hogy $\alpha_{i}=1, \alpha_{k}=1$ és $v_{k} \in \bar{N}\left(v_{i}\right)$. $\underline{\alpha}^{T}$ megengedett megoldás, ezért

$$
C_{i} \alpha_{i}+\sum_{v_{j} \in \bar{N}\left(v_{i}\right)} \alpha_{j} \leq C_{i}
$$

feltétel teljesül. Behelyettesítve $\alpha_{i}$ és $\alpha_{k}$ értékeit azt kapjuk, hogy

$$
C_{i}+1+\sum_{v_{j} \in \bar{N}\left(v_{i}\right), j \neq k} \alpha_{j} \leq C_{i} .
$$

Átrendezve az egyenlőtlenséget

$$
\sum_{v_{j} \in \bar{N}\left(v_{i}\right), j \neq k} \alpha_{j} \leq-1
$$

adódik. Ellentmondásra jutottunk, mivel az összeg minden tagja nemnegatív. Ezzel az állítást beláttuk.

További lehetőség a javításra, hogy a csúcsok színezésére más eljárásokat alkalmazunk, amelyek jobb korlátokat adnak. Mi a programokban csak a mohó színezőt használtuk.

\subsection{Az (5.2) korlátban a $C_{i}$ megválasztása lokális élszínezéssel}

Ebben az esetben is a (3.2) feltételeket módosítjuk, most azonban nem a csúcsokat színezzük, hanem az éleket. Ehhez tekintsük minden $v_{i}$ csúcs esetén a $v_{i}$ nemszomszédaiból álló részgráfokat $G$-ben. Vegyük egy adott részgráf összes élét, és színezzük őket a következő módon: az első él az 1 színt kapja. A második él 
esetén vizsgáljuk meg, hogy van-e közös csúcsa az első éllel. Közös csúcsból legfeljebb egy lehet, így két eset fordulhat elö: egy közös csúcs van, vagy nincs közös csúcs. Legyen az első él két csúcsa $a_{1}$ és $a_{2}$, a második él csúcsai pedig $b_{1}$ és $b_{2}$. Lehetséges esetek:

1. Egy közös csúcs van. Tegyük fel, hogy $a_{1}=b_{1}$ (az általánosság megsértése nélkül feltehetjük). Ha $a_{2}$ és $b_{2}$ között fut él, akkor a második él színe 2 , és azt mondjuk, hogy a két él klikket alkot, egyébként 1.

2. Nincs közös csúcs. Ha $\left\{a_{1}, a_{2}, b_{1}, b_{2}\right\}$ egy 4-klikk $G$-ben, akkor a második él színe 2, és azt mondjuk, hogy a két él klikket alkot, egyébként 1.

Tegyük fel, hogy az első $k$ élt kiszíneztük $s$ színnel. A $(k+1)$-edik él színének meghatározásához végezzük el a fenti vizsgálatot a korábbi élekkel, és tekintsük azt a legkisebb színszámú színosztályt, amelyben a $(k+1)$-edik él semelyik éllel nem alkot klikket. Ha van ilyen, akkor a $(k+1)$-edik él is bekerül ebbe a színosztályba, ha nincs, akkor a színe legyen $s+1$. Ezzel az éleknek egy élesített jó színezését kapjuk. Egy klikk összes éle különböző színü lesz, így az eljárás végén az előforduló legnagyobb színszám felső becslést ad a gráfban található $C$ maximum klikk éleinek számára. Ebből a $C$ csúcsainak számára vonatkozó becslést könnyen megkaphatjuk. Ha az élekre vonatkozó becslés $M$, akkor a $\left(\begin{array}{c}|C| \\ 2\end{array}\right) \leq M$ egyenlőtlenségből a $|C|$ értékére vonatkozó felső becslés másodfokú egyenlet megoldásából adódik: $|C| \leq\left[\frac{1+\sqrt{1+8 M}}{2}\right]$.

Színezzük ki minden csúcs esetén a csúcsok nemszomszédaiból alkotott részgráfok éleit a fenti színezéssel. Jelölje $K_{i}$ a $v_{i}$ nemszomszédai által kifeszített részgráf esetén kapott felső becslést a részgráfban található maximum klikk méretére.

A Croce-Tadei feltételek $i$-edik egyenlőtlenségét ebben az esetben is úgy javíthatjuk, ha $\bar{N}_{i}$ helyére $K_{i}$-t írunk:

$$
K_{i} x_{i}+\sum_{v_{j} \in \bar{N}\left(v_{i}\right)} x_{j} \leq K_{i}, \quad v_{i} \in V
$$

A (4) vegyes-egészértékü program (4.2) feltételét helyettesítsük a (8) feltétellel. Az így kapott programot jelöljük (9)-cel. Ezt megtehetjük, és az erre vonatkozó bizonyításokat megkapjuk, ha a 4.1. és a 4.2. Állításokban és bizonyításaikban a $C_{i}$ jelöléseket lecseréljük $K_{i}$-re.

Élszínezéssel erősebb korlátokat kaptunk, mint csúcsszínezéssel, viszont ebben az esetben az összes élt össze kellett hasonlítanunk, ezért hosszabb volt a futásidő. Ha egy $G$ gráf csúcsai $k$ színnel jól színezhetők, akkor $G$ élei élesítetten jól színezhetők $\left(\begin{array}{l}k \\ 2\end{array}\right)$ színnel. Ebből az adódik, hogy van olyan élesített élszínezés, amely nem ad rosszabb felső korlátot a klikkméretre, mint a csúcsok jó színezése. Természetesen egy éleket színező mohó algoritmus adhat rosszabb felső korlátot a klikkméretre, mint egy szerencsésebb mohó csúcsszínező. Az, hogy az élszínezés tipikusan jobb 
korlátokat ad, mint a csúcsszínezés, egy empirikus tény, amit a példafuttatások során tapasztaltunk.

\subsection{Az (5.3) korlátban az $M_{i}$ választása}

A lokális csúcs- és élszínezést nemcsak a Croce-Tadei egyenlőtlenségeknél alkalmazhatjuk, hanem a vegyes-egészértékü program

$$
z_{i} \leq U_{i} x_{i}, \quad v_{i} \in V \backslash\left\{v_{n}\right\}
$$

alakú feltételei esetén is.

$N^{+}\left(v_{i}\right)$ jelöli azokat a szomszédos csúcsokat, amelyek indexe $i$-nél nagyobb, $U_{i}$ pedig a $v_{i}$-böl $N^{+}\left(v_{i}\right)$-be érkezö élek súlyának összegét. Színezzük ki az $N^{+}\left(v_{i}\right)$ csúcsok által kifeszített $G$-beli részgráf csúcsait jól vagy éleit élesített jó színezéssel. Ha $v_{i}$ szerepel egy $C$ klikkben, akkor az $i$-nél nagyobb indexü szomszédai közül azok, amelyek szintén szerepelnek $C$-ben, klikket alkotnak egymással. Tegyük fel, hogy a színezéssel kapott becslés a részgráfban található maximum klikk méretére $L_{i}$, ami azt jelenti, hogy az $N^{+}\left(v_{i}\right)$ halmaz elemeiből legfeljebb $L_{i}$ szerepelhet $C$ ben. Ezért tekintsük a $v_{i}$-ből induló $N^{+}\left(v_{i}\right)$ csúcsokba érkező élek súlyai közül az első $L_{i}$ darab legnagyobb súly összegét, ezt jelölje $M_{i}$. Mivel $M_{i} \leq U_{i}$, ezért $U_{i}$ helyére $M_{i}$-t írva szorosabb korlátokat kapunk. A módosított feltétel:

$$
z_{i} \leq M_{i} x_{i}, \quad v_{i} \in V \backslash\left\{v_{n}\right\} .
$$

Legyen $C_{i}^{+}$az $N^{+}\left(v_{i}\right)$ csúcsok által kifeszített $G$-beli részgráfban található maximum klikk, és jelölje $s_{i}$ a $v_{i}$-ből az $C_{i}^{+}$csúcsokba futó élek súlyának összegét. $\left|C_{i}^{+}\right| \leq L_{i}$ és $s_{i} \leq M_{i}$.

4.3. Állítás. A (7) vegyes-egészértékű program optimális megoldása megadja a maximális élsúlyú klikket G-ben.

Bizonyítás. Azt kell megmutatnunk, hogy a (4.3) egyenlőtlenséget lecserélhetjük (5.3)-ra.

Legyen $C$ maximális élsúlyú klikk $G$-ben. A (4) vegyes-egészértékü program $C$-hez tartozó optimális megoldásában

$$
z_{i}=\left\{\begin{array}{cl}
\sum_{v_{j} \in N^{+}\left(v_{i}\right) \cap C} w_{e}\left(v_{i}, v_{j}\right), & \text { ha } v_{i} \in C, \\
0, & \text { ha } v_{i} \notin C .
\end{array}\right.
$$

$\left|N^{+}\left(v_{i}\right) \cap C\right| \leq\left|C_{i}^{+}\right| \leq L_{i} \leq\left|N^{+}\left(v_{i}\right)\right|$, ezért

$$
\sum_{v_{j} \in N^{+}\left(v_{i}\right) \cap C} w_{e}\left(v_{i}, v_{j}\right) \leq s_{i} \leq M_{i} \leq U_{i} .
$$

Ebből következik, hogy a $z_{i} \leq U_{i} x_{i}$ feltételt valóban lecserélhetjük a $z_{i} \leq M_{i} x_{i}$ egyenlőtlenségre. Ezzel az állítást beláttuk. 


\subsection{Az (5.4) korlátban az $S$ választása}

A programokat tovább javíthatjuk, ha az eredeti gráfot is kiszínezzük. Ezt globális színezésnek nevezzük. A kapott értéket jelöljük $S$-sel. Ez felső becslést ad a gráfban található maximum klikk méretére, ezért a korábbi programokhoz hozzávehetjük a

$$
\sum_{i=1}^{n} x_{i} \leq S
$$

feltételt. A tesztekben globális élszínezést használtunk a plusz feltétel megfogalmazásához.

\subsection{Példa}

Tekintsük a következő $G$ gráfot:

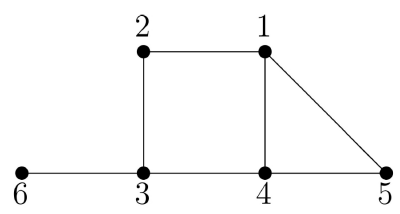

1. ábra. $G$ gráf

$G$-nek 6 csúcsa és 7 éle van. Az él átfogalmazásból adódó egészértékü program a maximum klikk problémára 6 változót és 8 feltételt tartalmaz. A változók 0-1 változók.

\begin{tabular}{|l|l|l|l|l|l|l|l|l|}
\hline & $x_{1}$ & $x_{2}$ & $x_{3}$ & $x_{4}$ & $x_{5}$ & $x_{6}$ & & \\
\hline & 1 & 1 & 1 & 1 & 1 & 1 & $\rightarrow$ & $\max$ \\
\hline$(1)$ & 1 & & 1 & & & & $\leq$ & 1 \\
\hline$(2)$ & 1 & & & & & 1 & $\leq$ & 1 \\
\hline$(3)$ & & 1 & & 1 & & & $\leq$ & 1 \\
\hline$(4)$ & & 1 & & & 1 & & $\leq$ & 1 \\
\hline$(5)$ & & 1 & & & & 1 & $\leq$ & 1 \\
\hline$(6)$ & & & 1 & & 1 & & $\leq$ & 1 \\
\hline$(7)$ & & & & 1 & & 1 & $\leq$ & 1 \\
\hline$(8)$ & & & & & 1 & 1 & $\leq$ & 1 \\
\hline
\end{tabular}

1. táblázat. Él átfogalmazás

A Croce-Tadei átfogalmazásból kapott egészértékű programot a 2. táblázat, a módosított Croce-Tadei átfogalmazásból (a (3) program a (3.2) korlát helyett az 
(5.2) feltétellel) kapott egészértékü programot pedig a 3. táblázat tartalmazza. A programokban 6 változó és 6 feltétel szerepel. A változók 0-1 változók.

\begin{tabular}{|c|l|l|l|l|l|l|l|c|}
\hline & $x_{1}$ & $x_{2}$ & $x_{3}$ & $x_{4}$ & $x_{5}$ & $x_{6}$ & & \\
\hline & 1 & 1 & 1 & 1 & 1 & 1 & $\rightarrow$ & $\max$ \\
\hline$(1)$ & 2 & & 1 & & & 1 & $\leq$ & 2 \\
\hline$(2)$ & & 3 & & 1 & 1 & 1 & $\leq$ & 3 \\
\hline$(3)$ & 1 & & 2 & & 1 & & $\leq$ & 2 \\
\hline$(4)$ & & 1 & & 2 & & 1 & $\leq$ & 2 \\
\hline$(5)$ & & 1 & 1 & & 3 & 1 & $\leq$ & 3 \\
\hline$(6)$ & 1 & 1 & & 1 & 1 & 4 & $\leq$ & 4 \\
\hline
\end{tabular}

2. táblázat. Croce-Tadei átfogalmazás

\begin{tabular}{|c|l|l|l|l|l|l|l|c|}
\hline & $x_{1}$ & $x_{2}$ & $x_{3}$ & $x_{4}$ & $x_{5}$ & $x_{6}$ & & \\
\hline & 1 & 1 & 1 & 1 & 1 & 1 & $\rightarrow$ & $\max$ \\
\hline$(1)$ & 2 & & 1 & & & 1 & $\leq$ & 2 \\
\hline$(2)$ & & 2 & & 1 & 1 & 1 & $\leq$ & 2 \\
\hline$(3)$ & 1 & & 2 & & 1 & & $\leq$ & 2 \\
\hline$(4)$ & & 1 & & 1 & & 1 & $\leq$ & 1 \\
\hline$(5)$ & & 1 & 1 & & 2 & 1 & $\leq$ & 2 \\
\hline$(6)$ & 1 & 1 & & 1 & 1 & 3 & $\leq$ & 3 \\
\hline
\end{tabular}

3. táblázat. Módosított Croce-Tadei átfogalmazás

A megengedett megoldások halmaza a három egészértékű program esetén azonos. Az $x_{i} \in\{0,1\}$ változókat a $0 \leq x_{i} \leq 1$ valós változókkal helyettesítve az egészértékü programok lineáris relaxációit kapjuk. A kérdés az, hogy a lineáris relaxációk megengedett megoldásainak $A_{1}, A_{2}, A_{3}$ halmazai hogyan viszonyulnak egymáshoz.

A Croce-Tadei átfogalmazás minden feltétele az él átfogalmazás bizonyos feltételeinek összege, amiből következik, hogy $A_{1} \subseteq A_{2}$. Egy egészértékü program feltételei megfeleltethetők hipersíkoknak. Kiszámítva a koordinátatengelyek és a hipersíkok metszetét, arra a következtetésre juthatunk, hogy $A_{3} \subseteq A_{2}$.

Legyen $P=(p, p, p, p, p, p)$ egy tesztpont. Ha $p=0.5$, akkor láthatjuk, hogy $P \in A_{1}, P \in A_{2}, P \notin A_{3}$.

Legyen $Q=(0, q, 0,0, q, 0)$ szintén egy tesztpont. Ha $q=0.75$, akkor láthatjuk, hogy $Q \notin A_{1}, Q \in A_{2}, Q \notin A_{3}$. Ha $q=0.66$, akkor $Q \notin A_{1}, Q \in A_{2}, Q \in A_{3}$. Végül, ha $q=0.5$, akkor $Q \in A_{1}, Q \in A_{2}, Q \in A_{3}$. 
A $q=0.66$ és a $q=0.75$ választások mutatják, hogy az él átfogalmazás $x_{2}+$ $x_{5} \leq 1$ feltétele nem következhet sem az eredeti, sem a módosított Croce-Tadei átfogalmazásból.

A lineáris relaxációk megengedett megoldásainak halmazai közötti kapcsolatot a következő ábra szemlélteti:

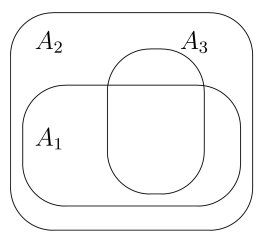

2. ábra. A megengedett megoldások halmazai

A 2. ábra nemcsak a példára, hanem általánosan is igaz. A következő ábrák azt mutatják, hogy bizonyos célfüggvényekre az él átfogalmazás, míg más célfüggvényre a módosított Croce-Tadei átfogalmazás ad jobb felső korlátot.

Az alábbi helyzetben az él átfogalmazás optimum értéke nagyobb, mint a módosított Croce-Tadei átfogalmazásban.

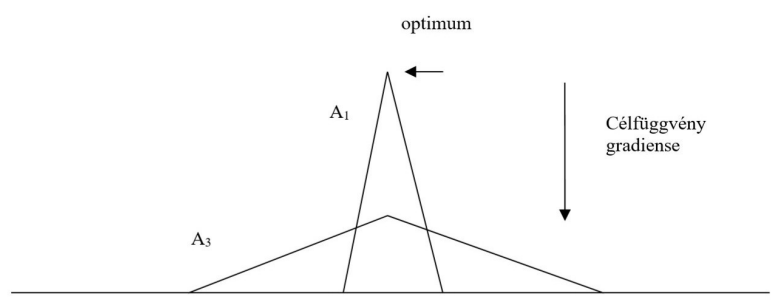

3. ábra. A célfüggvény gradiense vertikális

Ha a célfüggvény gradiense horizontális, akkor fordul a helyzet. A Croce-Tadei átfogalmazás optimum értéke nagyobb, mint az él átfogalmazás optimuma.

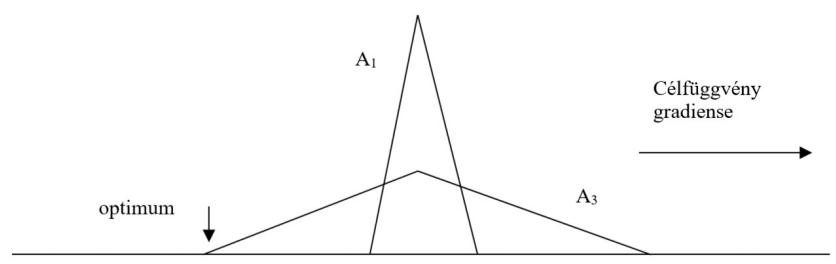

4. ábra. A célfüggvény gradiense horizontális 
A maximum klikk probléma él és Croce-Tadei átfogalmazásának megengedett megoldásai általában is úgy viszonyulnak egymáshoz, mint a példa esetében. Ha egy csúcssúlyozott maximum klikk problémát tekintünk, vagyis egy $c_{1} x_{1}+\ldots+$ $c_{n} x_{n}$ alakú célfüggvényt alkalmazunk, akkor a $c_{1}, \ldots, c_{n}$ együtthatók válaszhatók úgy, hogy az él átfogalmazás adja a kisebb optimumot, de válaszhatók úgy is, hogy a Croce-Tadei átfogalmazáshoz tartozik a kisebb optimum.

A maximális élsúlyú klikk probléma esetében a $z_{1}, \ldots, z_{n-1}$ új változók miatt a geometriai kép megváltozik. A két átfogalmazás összehasonlítására nem marad más eszközünk, mint numerikus kísérletek eredményeinek összehasonlítása. Ezen az alapon a Croce-Tadei átfogalmazás jobb becsléseket ad, mint az él átfogalmazás. Ez egy megfigyeléseken alapuló észrevétel, amelynek van a gyakorlatban is használható jelentősége, de nem szeretnénk matematikai értelemben vett bizonyított eredmény szintjére emelni.

\section{Számítási eredmények}

A módosított programokat a [6] cikkben található DIMACS gráfokon teszteltük. Ezek a gráfok nem élsúlyozottak, ezért a cikk szerzőihez hasonlóan az éleket a $w_{e}\left(v_{i}, v_{j}\right)=(i+j) \bmod 200+1$ módszerrel súlyoztunk, bár a [2] munka kritizálja ezt a gyakorlatot. Az eredményeket a 6 . táblázatban foglaltuk össze. A táblázatban az eredeti és a módosított programok lineáris relaxációinak optimum értékei szerepelnek. Az egyes oszlopok jelentését a 4. táblázat tartalmazza.

\begin{tabular}{c|l}
$|V|$ & csúcsok száma \\
\hline$|E|$ & élek száma \\
\hline$d$ & élsürüség \\
\hline optimális súly & a maximális élsúlyú klikk élsúlyainak összege \\
\hline LR & $\begin{array}{l}\text { az eredeti (4) vegyes-egészértékü program lineáris relaxáci- } \\
\text { ójának optimuma }\end{array}$ \\
\hline LP1 & $\begin{array}{l}\text { a (6) vegyes-egészértékü program lineáris relaxációjának } \\
\text { optimuma }\end{array}$ \\
\hline LP2 & $\begin{array}{l}\text { a (9) vegyes-egészértékü program lineáris relaxációjának } \\
\text { optimuma }\end{array}$ \\
\hline LP3 & $\begin{array}{l}\text { a (9) vegyes-egészértékü program lineáris relaxációjának } \\
\text { optimuma kiegészítve az (5.5) feltétellel }\end{array}$ \\
\hline LP4 & $\begin{array}{l}\text { az (5) vegyes-egészértékü program lineáris relaxációjának } \\
\text { optimuma az (5.2) feltétel helyett a (8) feltétellel }\end{array}$
\end{tabular}

4. táblázat. Az oszlopok jelentése a 6. táblázatban 
Az LR oszlopot összehasonlítva az LP1, LP2, LP3 és LP4 oszlopokkal láthatjuk, hogy jelentősen csökkentek az optimum értékek, minél több helyen módosítottuk a programot, annál jobb becsléseket kaptunk. Ez azonban azzal járt, hogy tovább tartott az egyes feltételek meghatározása.

Az optimum értékek csökkenésétől azt reméljük, hogy ez futásidő megtakarításhoz vezet. Az 5. táblázatban összefoglalt eredmények megerősítik ezt a várakozásunkat. Egészértékü programokkal kerestünk maximum klikket tesztgráfokban. A futásidőket az utolsó kettő oszlop tartalmazza. EP1 jelöli az (1) programmal (él átfogalmazás), kapott értékeket, és EP2 a módosított Croce-Tadei átfogalmazással (a (3) program a (3.2) korlát helyett az (5.2) feltétellel) kapott eredményeket.

\begin{tabular}{|l|rrr|rr|}
\hline gráf & $|V|$ & $|E|$ & $\omega(G)$ & EP1 (s) & EP2 (s) \\
\hline brock200_4 & 200 & 13089 & 17 & 1264.57 & 250.96 \\
c-fat200-2 & 200 & 3235 & 24 & 108.58 & 1.20 \\
c-fat500-2 & 500 & 9139 & 26 & 3920.36 & 88.95 \\
hamming6-4 & 64 & 704 & 4 & 4.71 & 1.28 \\
hamming8-2 & 256 & 31616 & 128 & 0.70 & 0.56 \\
johnson8-2-4 & 28 & 210 & 4 & 0.57 & 0.64 \\
johnson8-4-4 & 70 & 1855 & 14 & 0.87 & 0.72 \\
johnson16-2-4 & 120 & 5460 & 8 & 176.47 & 0.57 \\
keller4 & 171 & 9435 & 11 & 198.16 & 63.67 \\
MANN_a9 & 45 & 918 & 16 & 0.77 & 0.68 \\
\hline
\end{tabular}

5. táblázat. Futásidők

\section{6. Összefoglalás}

Jelen munkában megmutattuk, hogy a maximális élsúlyú klikk problémát megoldó (4) vegyes-egészértékü program módosítására milyen lehetőségeink vannak csúcs- és élszínezés alkalmazásával, továbbá hogy az általunk tesztelt gráfok esetén az új programok lineáris relaxácóinak optimumai hogyan közelítették az eredeti optimumokat. A kutatás folytatására további lehetőség a programok módosítása más gráfszínező eljárásokkal, kernelizálással és kombinatorikus alapú metszősíkokkal.

\section{Köszönetnyilvánítás}

Jelen munka az Innovációs és Technológiai Minisztérium ÚNKP-19-2 kódszámú Új Nemzeti Kiválóság Programjának szakmai támogatásával készült. 


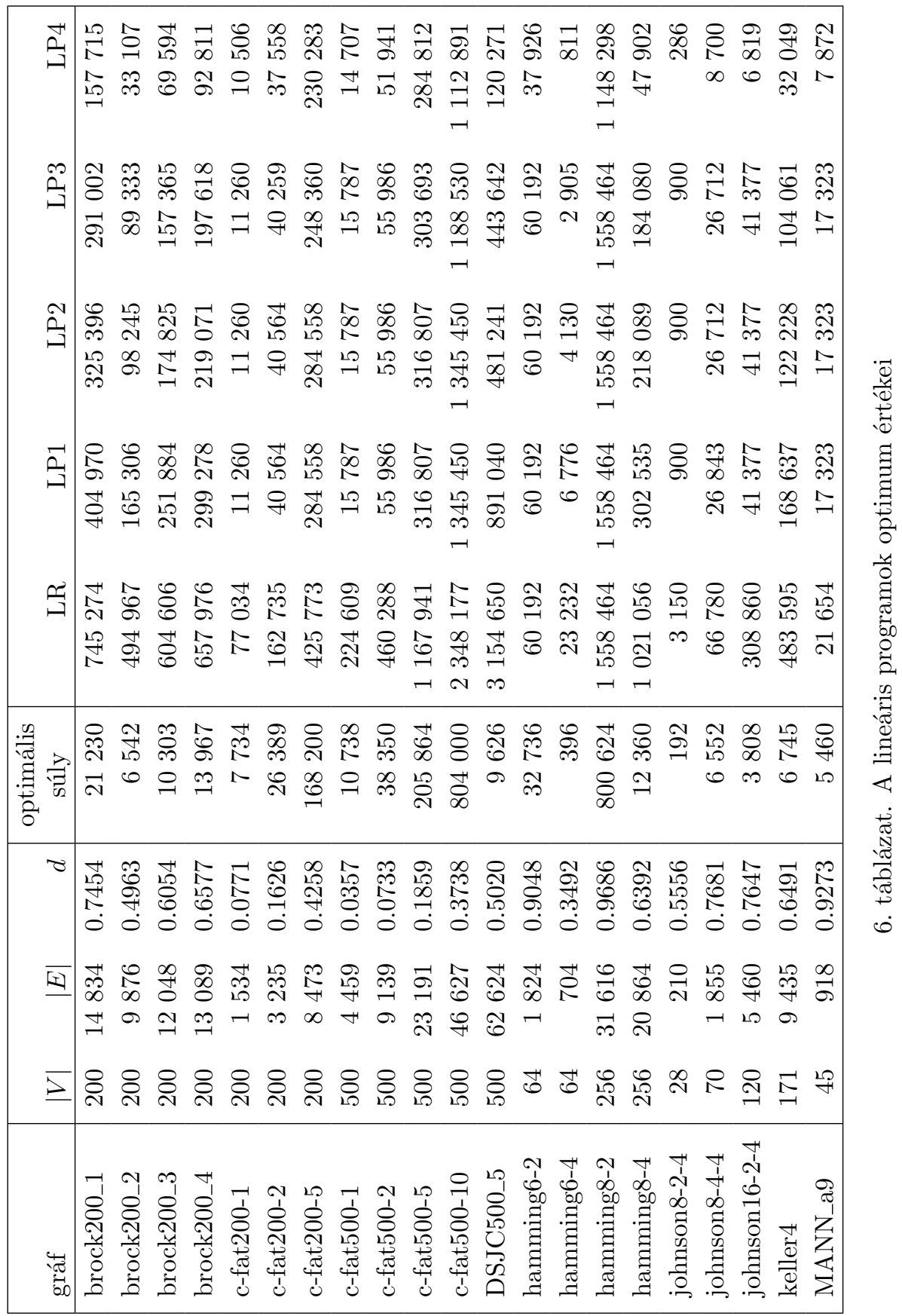




\section{Hivatkozások}

[1] Croce, F. D. And TAdeI, R.: A multi-KP modeling for the maximum-clique problem, European Journal of Operational Research, Vol. 73 No. 3, pp. 555-561 (1994). DOI: 10.1016/0377-2217(94)90252-6

[2] McCreesh, C., Prosser, P., Simpson, K. and Trimble, J.: On Maximum Weight Clique Algorithms, and How They Are Evaluated, In: Beck J. (eds) Principles and Practice of Constraint Programming. CP 2017. Lecture Notes in Computer Science, Springer, Cham, Vol. 10416 (2017). DOI: 10.1007/978-3-319-66158-2_14

[3] Moon, J. W. and Moser, L.: On cliques in graphs, Israel J. Math., Vol. 3, pp. 23-28 (1965). DOI: $10.1007 / \mathrm{BF} 02760024$

[4] Östergård, P. R.: A new algorithm for the maximum-weight clique problem, Electronic Notes in Discrete Mathematics, Vol. 3, pp. 153-156 (1999).

DOI: 10.1016/S1571-0653(05)80045-9

[5] Pullan, W.: Approximating the maximum vertex/edge weighted clique using local search, Journal of Heuristics, Vol. 14, pp. 117-134 (2008). DOI: 10.1007/s10732-007-9026-2

[6] Shimizu, S., Yamaguchi, K. And Masuda, S.: A Branch-and-Bound Based Exact Algorithm for the Maximum Edge-Weight Clique Problem, In: Lee R. (eds) Computational Science/Intelligence \& Applied Informatics. CSII 2018. Studies in Computational Intelligence, Springer, Cham, Vol. 787 (2019). DOI: 10.1007/978-3-319-96806-3_3

[7] Shimizu, S., Yamaguchi, K. and Masuda, S.: A maximum edge-weight clique extraction algorithm based on branch-and-bound, Discrete Optimization, Vol. 37, paper: 100583 (2020). DOI: 10.1016/j.disopt.2020.100583

[8] Shimizu, S., Yamaguchi, K. and Masuda, S.: Mathematical programming formulation for the maximum edge-weight clique problem, IEICE Transactions on Fundamentals of Electronics, Communications and Computer Sciences (in Japanese), Vol. J100-A No. 8, pp. 313-315 (2017).

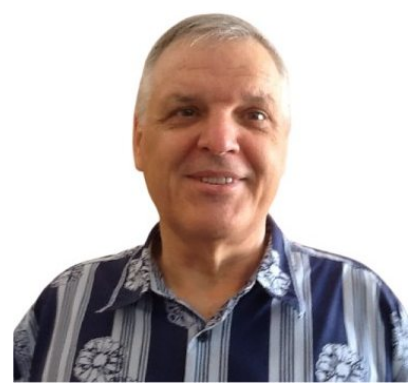

Szabó Sándor 1954-ben született Karcagon. Az Eötvös Loránd Tudományegyetemen tanult matematikát és fizikát. Jelenleg a Pécsi Tudományegyetem Matematikai és Informatikai Intézetében dolgozik. Fő érdeklődési területe a diszkrét matematika és alkalmazásai.

Szabó Sándor

Pécsi Tudományegyetem

Alkalmazott Matematika Tanszék

7624 Pécs, Ifjúság útja 6 .

szabos@ttk.pte.hu 


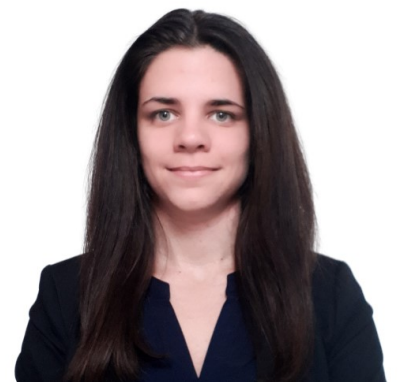

Sztojkovics Dóra

Pécsi Tudományegyetem 7624 Pécs, Ifjúság útja 6. sztojkovics@gmail.com
Sztojkovics Dóra 1996-ban született Pécsett. 2015-ben kezdte meg tanulmányait matematika alapszakon a Pécsi Tudományegyetemen. A 34. Országos Tudományos Diákköri Konferencián első helyezést ért el Tanulásés Tanításmódszertani - Tudástechnológiai Szekcióban. Következő tanévben elnyerte az ÚNKP ösztöndíjat, és új kutatási területe a diszkrét matematika lett. 2020ban alkalmazott matematikus diplomát szerzett.

\section{LINEAR PROGRAMS FOR THE EDGE WEIGHTED MAXIMUM CLIQUE PROBLEM}

\section{SÁndor Szabó, Dóra Sztojkovics}

Finding an edge weighted maximum clique in a given graph is an interesting problem and has many important applications. An earlier work [6] claims that a solver based on combinatorial considerations and exhaustive search outperforms solvers based on linear and quadratic programming. In this paper we propose modifications in the linear program reformulation of the edge weighted maximum clique problem. The modifications are based on coloring the nodes and edges of the graph. In order to assess the performance of the programs we carried out numerical experiments. 